\title{
INCREASING THE SECURITY LEVEL IN THE SLOVAK REPUBLIC
}

Increasing the security level in every country is a complicated process that affects all spheres of social life and requires a longer period of time. The improvement of the security system in the Slovak Republic has been taking place continuously since the country joined the European Union and NATO and has not been finished so far.

Key words: security, security system, public administration, risks, crisis situations

\section{Introduction}

An ambitious objective of every government is to create optimal conditions for achievement of ever-increasing standard of living of all inhabitants. A necessary prerequisite to achieve the objective is not only a high level of national economy but also purposeful and efficient functioning of the whole system of public administration. Public administration has to be developed in harmony with changing external and internal conditions induced by new requirements. On the other hand, there are fewer and fewer available sources in the public sector, which brings pressures to reduce the state administration on central and local levels, its decentralization and transfer of competences to regional self-administration.

Present society cannot develop continuously in permanently changing conditions without complete provision of not only internal but also external security. Security has to be perceived as the state of social, natural, technical, technological system or any other system which in concrete internal and external conditions enables fulfillment of given functions and their development in compliance with interests of man and society. The security of Slovakia and its citizens is a complicated phenomenon consisting of a whole series of elements, internal and external phenomena as well as concrete processes and activities. It can hardly be secured without adopting specific legal regulations among which are laws, legal norms of lower legal validity but also international agreements and standards.

Since 1993 when we started to build a new legal environment in the Slovak Republic first laws and legal norms of lower legal validity have appeared and gradually formed a legal framework of crisis management. Its fundamental element is the Constitution of the Slovak Republic No. 460/1992 Coll. in the wording of further regulations, which provides basic human rights and freedoms and protects life as the basic value. An important role in this process was played by Law of the National Council of the Slovak Repub- lic No. 42/1994 Coll. on civil protection of population in the wording of further regulations, which is, after a series of partial amendments, also at present the functional part of the legal environment of crisis management. The greatest number of laws was approved in the beginning of the 21st century when the Slovak Republic was getting ready for its accession to the EU and NATO. The extreme effort to meet all the requirements and standards of the European Union on the one hand, and a non-uniform attitude and split attitude of individual departments on the other hand, resulted in a series on nonsystematic steps having negative impact on the level of harmony in the crisis management legal environment.

As it comes from the audit of the state crisis management approved by the government of the Slovak Republic and also from the Complex Plan of building and further development of security system of the Slovak Republic and also from the Proposal of measures for the material "The objective of building and further development of the security system of the Slovak Republic up to the year 2010" the legal environment is not sufficiently interconnected and there are many unanswered questions in it. A significant shortcoming the crisis management has been facing since the setting up of the Slovak Republic has been an absence of a unified interpretation of basic terms used in the area of crisis management. The accession to the EU and NATO did not solve the problem and other new terms which are not correctly translated and understood in our mother tongue appear continuously.

The state security is the state which enables functioning, stability and development of the country, preserves peace, sovereignty, territorial wholeness and frontier indefatigability, internal order within the state, fundamental rights and freedoms of citizens and protection of lives and health of citizens, property and environment. The state security can be achieved through a wide range of tools among which is security policy of the state. It can be defined as a set of principles and procedures implemented to achieve a desired

\footnotetext{
* Ladislav Simak

Department of Crisis Management, Faculty of Special Engineering, University of Zilina, Slovakia, E-mail: Ladislav.Simak@fsi.uniza.sk
} 
level security of the system. The security policy of the country is then a set of tools and procedures to achieve basic aims and objectives of the country in the field of defense, protection and internal order within the country and its citizens.

The priorities of security policy of the Slovak Republic were defined in the security strategy which expresses objectives and needs of citizens and the state and respects the EU security strategy. The present government has identified them in its Programme Proclamation and implements them in its activities both in domestic and foreign policies. To the basic objectives to achieve a higher level of security in Slovakia belong the following:

- To permanently take steps to provide security for citizens of the Slovak Republic and its territorial wholeness, sovereignty, independence and identity,

- To protect basic human rights and freedoms of citizens in every situation, including crisis situations,

- To develop democratic state arrangement, legal state and market economy in the Slovak Republic,

- To provide sustainable economic, social, environmental and cultural development of society and diversification of sources together with protection of critical infrastructure of the state,

- To participate in providing security and stability of EU member states NATO aliens,

- To foster good relations with other countries, to develop all kinds of mutually advantageous cooperation and to support partnerships and alliances with countries we share common principles and interests,

- To protect and foster international order, freedom, democracy, peace and stability in the world and uphold human rights,

- To foster transatlantic strategic partnership and support the extension of NATO and EU in the Euro-Atlantic space [1].

\section{A Theoretical Treaty of the System of Crisis Management in Public Administration}

To systematically solve the Security System of the Slovak Republic, a team of workers of the Crisis Management Department presented in 2003 a project draft for the VEGA draft agency under the title "A Model of Crisis Management in Public Administration". The project was approved under the project number $1 / 1259 / 04$ and its solution began in 2004.

In the introductory stage of the solution a detail analysis of the contemporary situation of crisis management in the conditions of the Slovak Republic was carried out. The researchers outlined criteria by means of which they were able to assess the level of crisis management in different branches. They analyzed the task of each branch within the security system of the Slovak Republic and pointed out the structure of their mutual relations. Then they participated in the preparation of materials assessing the current situation in the building of the security system in the Slovak Republic and together with a commission of the deputy prime minister of the Slovak Republic they evaluated also the process of crisis management and its efficiency after the accession to the EU and NATO. In relation to the achieved results they prepared introduc- tory materials which could have been used as amendments to the conception of the top level of security system of the Slovak Republic.

Within the process of theoretical and methodological unification of crisis management terminology the authors suggested to create a dictionary of crisis management terminology. On the basis of the decision of the cross-sectional commission almost one hundred basic and most frequently used terms were chosen. Within the period from September to October 2004 the team of researchers compiled A Dictionary of Crisis Management Terms in the volume agreed upon during the period of cross-sectional reviewing. The compiled dictionary was in the first stage published as study material for students of the faculty (ISBN 80-88829-75-5) and simultaneously, it was sent for cross-sectional reviewing. At the seminar held on 21 October 2004 in the hotel Bôrik in Bratislava it was declared that the expectations of prevailing majority of representatives of participating sectors were met. Practically all of them evaluated the presented material in a highly positive way agreed that after partial comments and completion of some terms the material could be administratively modified and presented at the session of the Security Council of the Slovak Republic and subsequently also of the Government of the Slovak Republic.

The Office of the Security Council of the Slovak Republic presented the modified dictionary to the Security Council of the Slovak Republic which, on its 10th session held on 14 June 2005 approved by its decree No 89 "Activities and tasks of the cross-sectional terminological commission". The commission will further continue in the process of completing and updating the terminological dictionary. The process of approving the dictionary was finished on 6 July 2005 when the government of the Slovak Republic discussed and by its decree No 523 approved the "Terminological dictionary in the area of crisis management and principles of its usage". The Slovak Republic government recommended the terms to be used in legislative process in formation of new legal norms as well as in amendment of effective legal norms of crisis management. A shortcoming of the completed process was the formulation through which the government only recommended the usage of approved terms.

A range of possible effect of the state administration and selfadministration during crisis solution in society was defined and consequences of social crisis and their influence on population were analyzed. The structure, tasks, internal and external relations of the integrated rescue system and its elements were assessed in detail. Consequently, the system of crisis management during crisis of non-military character of a great extent was optimized from the point of view of structure and competences. To support the suggested solution the research in compliance with outlined objectives at the level of central authorities of the state administration was carried out.

Further, a complex logical model of crisis management in public administration was completed and its chosen parts were optimized focusing on the solution of crisis phenomena at the level of central authorities of the state administration. Consequently, methodolo- 
gies of crisis management were worked out and non-traditional methods of solution of chosen crisis phenomena were designed. Results achieved during the project solution were continuously presented in conferences and published in journals, mainly in Civil Defense. The conclusions were simultaneously used in the commission of vice-chairman of the security council of the Slovak Republic and conditions for the plan of gradual transformation of the security system of the Slovak Republic were created. On 10 October 2005 there was a meeting of the members of the research team with a working group of the deputy prime minister of the government of the Slovak Republic in the hotel Bôrik in Bratislava, during which the "Proposal of the change in the conception of security system of the Slovak Republic" was completed.

Another concrete output of the project was the Analysis of impact of reorganization of public administration to the level of crisis management in authorities of local administration and territorial self-administration. The analysis was carried out on the basis of the requirement delivered by the authorized representative of the government of the Slovak Republic responsible for reorganization of public administration. Within the analysis the transformation of public administration was assessed in all its complexity from the point of view of functionality of crisis management in public administration and capabilities of authorities of local state administration and self-administration to take preventive measures and at the same time to solve crisis situations. The emphasis was laid on the cooperation of the local state administration and self-administration and their mutual links in the area of crisis management. The SWOT analysis was done with the aim to define strong and weak points of transformation of the local state administration and also opportunities and threats produced by a wider safety environment. The analysis showed that the weakest point in the whole system of crisis management were villages, mainly those having a lower number of inhabitants. The best solution seems to be to connect such villages and create common offices in which crisis management could be performed in a way of transformation of state administration activities.

On the basis of the project results and mentioned complex assessments the staff engaged in the analysis preparation suggested the following:

- to modify the conception of the security system on the basis of the presented proposals,

- to make modifications of particular legal norms in the area of security with emphasis on:

- the change in the responsibility of the regional security council from a decision-making body to advisory and to abolish the district security council,

- transformation of the Central Crisis Headquarters and Main Post of Management to a Unified Crisis Headquarters of the Slovak Republic formed on the basis of the National Centre of Crisis Management which would be the executive body of the Slovak Republic government to solve crisis situations,

- amendments to constitutional law No. 227/2002 Coll. on security of the country during war, state of war, martial law and state of emergency,
- legislative amendment to the formation of the fifth crisis state under the name of emergency state,

- working out a new law on crisis management of the country,

- to create the Situational and Assessment Centre of the Slovak Republic as a permanent above-sectional, professional body of the Slovak Republic government designed for continuous monitoring and analysis of security situation in the Slovak Republic and abroad,

- to specify conditions for gradual formation of the central body of the state administration in the area of crisis management,

- to create conditions for transformation of state administration in the area of crisis management to villages and for this purpose to create common offices within micro-regions or centralized villages,

- to abolish crisis management departments of district authorities and part of their staff employ in villages with extended legislature [8].

Presentation of the results was during educational courses for employees of sections of crisis management of central bodies of the state administration which took place in 2005 with the support of the European social fund (Unified programme document NUTS II - Bratislava, objective 3 - human sources development). More than 180 crisis managers from central bodies of the state administration as well as from the local state administration in Bratislava were trained in two three-month courses. In the subject Crisis management the participants got acquainted with the project results with special emphasis on proposals of changes in the security system of the Slovak Republic on the top level of the state management (creation of the National Centre of Crisis Management and Situational and Assessment Centre, transformation of the Central Crisis Headquarters, ....).

Apart from the above mentioned, the project results were also discussed in the section of Crisis Management on the $10^{\text {th }}$ and $11^{\text {th }}$ international scientific conferences "Solution of Crisis Situation in Specific Environment" organized by the Faculty of Special Engineering of Žilina University in Žilina in June 22 - 23, 2005 and June $29-30,2006$. Several members of the research team presented their contributions at the conferences. Their presentations were discussed and commented on by specialists from practical setting as well as representatives of research institutions and institutions of higher learning. Majority of reactions was positive and confirmed the correctness of the solution.

Last but not least, the project results were published in some articles in the journal Civil Defense - revue for civil protection of citizens. The mentioned articles have considerable importance for professional practical setting and shaping the opinion on the level of central bodies of the state administration, local state administration as well as executive bodies of crisis management. 
3. Changes in opinions on the security system of the Slovak Republic and on the system of crisis management in public administration after the election in 2006

To solve crisis phenomena on the level of the Slovak Republic government it is necessary to create an efficient system of crises solution which will be a complex of subsystems of crisis management of individual branches. Their competences and possibilities as well as powers and tools should jointly provide new quality and thus also inevitable conditions for solution of any crises.

The increase of the security level of the Slovak Republic depends on a degree of harmonization of security needs with development of security environment as well as with economic, political, social, demographic and scientific and technical potential and capabilities of the state. The state has to provide the active security environment, act preventively and avoid stresses and crises. On the other hand, it has to be capable to solve - early, decisively and efficiently - all crisis situations by means of established forces, tools and sources.

In spite of the efforts of numerous specialists, the Security System of the Slovak Republic has not been completed. Although expert groups worked for several years, their results were not approved and accepted by the decision making bodies. All the efforts led only to partial success having mostly the character of legislative measures and other presented documents were put aside.

The present state administration has decided to prepare a new objective of building and further development of the security system of the Slovak Republic up to 2010. Crisis managers have again a challenge to pursue three basis steps which are mutually interrelated and represent institutional solutions of the basis problems:

- to optimize the security system of the Slovak Republic,

- to prepare the project of the national body of crisis management,

- to create a situational and analytical centre of the Slovak Republic.

The process of completion of the security system must be of a systematic character. It should, therefore, be based on a complex assessment of responsibilities, competences and tasks of all central bodies of the state administration, local state administration and territorial self-administration and relations among them in the area of crisis management. The transformation of institution of security system has to be carried out simultaneously with changes in executive bodies of crisis management among which are armed forces, armed security forces and other executive forces including appointed legal and physical entities. These principles have not been met. Proclamations of top representatives of the Slovak Republic government about abolition of regional offices and reductions in the state administration were not preceded by any serious analyses and did not have any positive impact on the further development of the security system.

Within the framework of preparation of the principles to be included in the Objective of building and further development of security system of the Slovak Republic up to 2010 the emphasis has to be put on:

- the explicit definition of objectives which should provide a higher quality and level of crisis management,

- the unification of content of terms which are to be used in the Objective and have not been processed in the Terminological dictionary of crisis management,

- the harmonization of activities and processes which might be shared to provide external and internal security of the country (military and non-military risks and crisis situations resulting from them),

- the assessment of inevitability of above-sectional coordination in the area of crisis management,

- the assessment of level of sources to provide balance of needs of the security system,

- the creation of a unified system of crisis management planning and specification of principles concerning the implementation of the plans in the process of crisis situations,

- the preparation of proposals of legislative changes.

\section{Conclusion}

The process of providing a higher level of security in the Slovak Republic has its positive moments but also a number of faults and mistakes. In spite of the fact that several times it has been very near to qualitative changes, responsible representatives have not found enough courage to pursue the changes. Again, we are at the turning point from which there are several ways. It will be very important for those who are responsible for future development to choose the right way, or at least, to choose the direction which seems to be the most suitable in given conditions. The National Council approved the law through which it transformed the competences from the regional authority to the district authority in the seat of the region and the proposal of measures for preparation of the material "Plan of building and further development of security system of the Slovak Republic up to 2010" has been rejected. The security of Slovakia is an inevitable prerequisite for peaceful life of each citizen and therefore it has to receive due attention of all of us.

\section{References:}

[1] Security Strategy of the SR (in Slovak), 2005 
[2] Collective work of authors: A Project for Education of Crisis Management Departments Employees Working in Central Bodies of State Administration (in Slovak), The Centre of Education MPSVaR, Bratislava, 2005, ISBN 80-89125-06-9

[3] Collective work of authors: Survey of Basic Terms in the Field of Crisis Management (in Slovak), FSI Zilinska univerzita, Zilina 2004

[4] Proposal of frame arrangements for elaboration of materials Intention of Building and Further Development of the SR Security System by the Year 2010 (in Slovak), Office BR SR, Bratislava, 2007

[5] NOVAK, L. et al.: Crisis Planning (in Slovak), Zilinska univerzita, Zilina, 2005, ISBN 80-8070-391-4

[6] Valid Legal Enactments of the SR in the Field of Crisis Management (in Slovak)

[7] SIMAK, L.: Crisis Management in Public Administration (in Slovak), FSI Zilinska univerzita, Zilina, 2001, ISBN 80-88829-13-5

[8] Final report of the grant task No. 1/1259/04 VEGA entitled Model of Crisis Management in Public Administration (in Slovak), FSI Zilinska univerzita, Zilina, 2007. 